\title{
Efek Fotoreduksi Besi dari Fraksi Daun Cengkih (Eugenia aromatica)
}

Lysa L. Datua*, Johnly A. Roronga, Edi Suryantoa

aJurusan Kimia, FMIPA, Unsrat, Manado

K A T A K U N C I

Daun cengkih

Fitokimia fenolik

Fotoreduksi

\section{K E YW O R D S}

Clove leave

Phenolic phytochemicals

Photoreduction
AVAILABLE ONLINE 10 Februari 2015

\begin{abstract}
A B S T R A K
Telah dilakukan penelitian untuk menganalisis kandungan fitokimia fenolik, flavonoid, tanin dari limbah daun cengkih dan menguji kemampuannya dalam memfotoreduksi. Daun cengkih diekstrak dengan pelarut etanol $80 \%$ secara refluks selama 2 jam dan dipartisi dengan petroleum eter (PE), etil asetat (EA), $n$-butanol (B), etanol (E) dan akuades (Aq). Selanjutnya ekstrak hasil partisi dianalisis kandungan fitokimia fenolik, flavonoid, dan tanin. Pengujian fotoreduksi dilakukan pada cahaya flourescents dengan konsentrasi 1000 ppm selama 5 jam.

Hasil penelitian menunjukkan bahwa ekstrak EA memiliki kandungan fenolik, flavonoid dan tanin yang paling tinggi serta menunjukkan efek fotoreduksi yang baik dibandingkan ekstrak lainnya.

A B S T R A C T

Research had been carried out to analyze the phytochemicals phenolic, flavonoids, tannins of clove leave and test the ability in photoreduction. Clove leave extracted with ethanol $80 \%$ in reflux for 2 hours and partitioned with petroleum ether $(P E)$, ethyl acetate $(E A), n$ butanol (B), ethanol (E) and aquades (Aq). Then extracts were analyzed the content of phytochemicals phenolic, flavonoids, and tannins. The results extract partition read on a spectrophotometer UV-Vis and IR. The photoreduction tests performed on fluorescent light with a concentration of 1000 ppm for 5 hours.

The results showed that extract EA is the most high content of phenolic, flavonoids and tannins and good effects in photoreduction than other extracts.
\end{abstract}

\section{Pendahuluan \\ Indonesia merupakan negara pertanian yang banyak memproduksi hasil pertaniannya, sehingga dapat menghasilkan limbah yang belum bisa dimanfaatkan secara optimal. Beberapa hasil limbah yang dihasilkan yaitu seperti sekam padi, tongkol jagung, akar bawang daun, dan masih banyak lagi. Adapun hasil limbah dari produk-produk alami sebagai sisa dari proses kehidupan suatu flora, seperti kayu, batang, dan daun, belum diolah dan dimanfaatkan bagi kehidupan manusia sehari-hari. \\ Tanaman cengkih dapat menghasilkan limbah seperti pada bagian batang, kayu dan terutama daunnya. Pada bagian tersebut hanya dibiarkan jatuh betebaran dan berserakan sampai membusuk.}

Limbah daun cengkih merupakan sumber bahan organik yang tersedia dalam jumlah banyak dan diproduksi terus menerus. Limbah daun cengkih mengandung senyawa metabolit sekunder, dapat digunakan sebagai sensitiser alami. Daun cengkih mengandung bahan utama komponen senyawa fenolik, flavonoid, dan tanin yang melimpah dapat diolah menjadi bahan biosensitiser yang bermanfaat dalam pertumbuhan tanaman dan meningkatkan kesuburan tanah dengan bantuan cahaya matahari (Rorong et al., 2012).

Senyawa fenolik seperti asam humat mempunyai kemampuan dalam mereduksi beberapa ion logam yang teroksidasi (Aiken et al., 1985). Menurut Rorong et al. (2012), senyawa fenolik, flavonoid dan tanin dapat diekstraksi dari daun 
cengkih dengan menggunakan pelarut metanol 40\%, $60 \%, 80 \%$ dan akuades dengan kemampuan dalam memfotoreduksi $\mathrm{Fe}^{3+}$ menjadi $\mathrm{Fe}^{2+}$ tertinggi terdapat pada ekstrak metanol $80 \%$.

Menurut Foth (1984), besi memiliki peranan penting dalam sistem enzimatik pada sintesis klorofil. Bila terjadi defisiensi besi akan mengakibatkan klorosis pada daun tanaman akan berwarna kuning terang, dengan mula-mula muncul pada daun muda dan berkembang pada lembaran antara tulang dan daun dan pada akhirnya dapat meliputi seluruh daun. Pada umumnya tanaman mengambil besi dalam bentuk ion $\mathrm{Fe}^{2+}$ dari alam, akan tetapi ketersediaan besi di alam dalam bentuk ion $\mathrm{Fe}^{3+}$. Oleh sebab itu ion $\mathrm{Fe}^{3+}$ harus direduksi terlebih dahulu menjadi $\mathrm{Fe}^{2+}$ agar dapat berasosiasi dengan suatu senyawa faktor yang terdapat di dalam tanah yaitu humin, asam humat, dan asam fulvat (Aiken et al., 1985). Tujuan penelitian ini adalah menganalisis kandungan fitokimia fenolik, flavonoid, tanin dari limbah daun cengkih dan menguji kemampuan dalam memfotoreduksi besi.

\section{Metode}

Sampel yang digunakan pada penelitian ini adalah daun cengkih yang berasal dari Kelurahan Papakelan Kecamatan Tondano Timur Kabupaten Minahasa Provinsi Sulawesi Utara. Bahan kimia yang digunakan yaitu, etanol, petroleum eter, etil asetat, $n$ heksan, $n$-butanol, natrium karbonat, reagen FolinCiocalteau, vanilin, alumunium klorida, asam klorida, 2,2 bipiridin $0,07 \%$, larutan ion logam $\mathrm{Fe}^{3+}$ yang diperoleh dari Merck (Darmstat, Germany) serta akuades. Peralatan yang digunakan dalam penelitian ini adalah mikropipet, seperangkat alat refluks, vorteks, oven Mammert, ruang penyinaran berukuran $70 \times 50 \times 60 \mathrm{~cm}$ yang dilengkapi dengan cahaya flouresen 45 watt Phillips cool white, spektrofotometer UV-Vis Thermo Scientific Genesys 20, spektrofotometer UV-Vis Genesys 10S, dan spektrofotometer IR Shimadzu.

\subsection{Ekstraksi}

Daun cengkih diekstraksi menggunakan pelarut etanol 80\%. Sebanyak 500 g serbuk daun cengkih dimasukkan dalam labu kaca pemanas, ditambahakan pelarut 1,5 L hingga sampel terendam semuanya, kemudian dipanaskan selama 2 jam pada 78-90 ${ }^{\circ} \mathrm{C}$. Filtrat disaring lalu diuapkan untuk menghilangkan pelarutnya dengan menggunakan evaporator sehingga diperoleh ekstrak daun cengkih. Selanjutnya, ekstrak daun cengkih dipartisi dengan 5 macam pelarut dan menghasilkan 5 macam ekstrak yaitu, petroleum eter (PE), etil asetat (EA), n-butanol (B), etanol (E) dan akuades (Aq). Partisi dilakukan 3 kali pengulangan.

\subsection{Penentuan Kandungan Total Fenolik, Flavonoid, dan Tanin}

Kandungan total fenolik ekstrak daun cengkih ditentukan dengan menggunakan metode FolinCiocalteau (Conde et al., 1997). Absorbansi ekstrak dibaca pada spektrofotometer visibel dengan $\lambda 750$ $\mathrm{nm}$. Kandungan total fenolik dinyatakan sebagai $\mathrm{mg}$ ekivalen asam galat/L ekstrak. Penentuan kandungan total flavonoid ekstrak daun cengkih ditentukan menurut metode Meda et al. (2005). Absorbansi dibaca $\lambda 415 \mathrm{~nm}$. Kandungan total flavonoid dinyatakan sebagai mg ekivalen kuesertin/L ekstrak. Penentuan kandungan total tanin ekstrak daun cengkih ditentukan menurut metode Julkenen-Tito (1985). Absorbansi dibaca pada $\lambda 500 \mathrm{~nm}$. Kandungan total tanin terkondensasi dinyatakan sebagai mg ekivalen ketekin/L ekstrak.

\subsection{Fotoreduksi $\mathrm{Fe}^{3+}$ dengan Ekstrak Daun Cengkih dan Penentuan Kandungan Besi Tereduksi}

Ekstrak limbah daun cengkih 1000 ppm diinteraksikan dengan larutan ion logam $\mathrm{Fe}^{3+}$ pada konsentrasi 25 ppm yang dilarutkan ke dalam akuades. Sampel diambil sebanyak $20 \mathrm{~mL}$ dan dimasukkan ke dalam botol serum berukuran $25 \mathrm{~mL}$. Selanjutnya dibuat kontrol (tanpa ekstrak) masingmasing $20 \mathrm{~mL}$ dimasukkan ke dalam botol serum dengan salah satu botol dibungkus menggunakan aluminium foil (tanpa cahaya). Sampel tersebut diletakan ke dalam kotak cahaya flourescents selama 5 jam, cuplikan diambil sebanyak 5 kali yaitu $0,1,2$, 3 , dan 5 jam. Selanjutnya setelah selesai penyinaran dilakukan analisis kadar besi yang tereduksi. Interaksi dari limbah daun cengkih dengan besi dievaluasi efeknya terhadap fotoreduksi ion $\mathrm{Fe}^{3+}$. Sebanyak 2 $\mathrm{mL}$ sampel ditambahkan dengan $0,5 \mathrm{~mL}, 2,2$ bipiridin $0,07 \%$ dan divorteks selama 2 menit. Absorbansi sampel dibaca pada $\lambda 520 \mathrm{~nm}$ dengan menggunakan spektrofotometer UV-Vis pada suhu ruang. Kandungan besi yang tereduksi dinyatakan sebanyak $\mathrm{mg} / \mathrm{L}$ untuk kurva kalibrasi menggunakan $\mathrm{NH}_{4} \mathrm{Fe}^{2+}\left(\mathrm{SO}_{4}\right)_{2} .6 \mathrm{H}_{2} \mathrm{O}$ sebagai standar.

\section{Hasil dan Pembahasan}

\subsection{Kandungan Total Fenolik, Flavonoid dan Tanin}

Hasil ekstraksi daun cengkih dibuat dengan konsentrasi $1 \mathrm{mg} / \mathrm{mL}$ kemudian diuji kandungan total fenolik, flavonoid, da tanin. Hasil analisis kandungan total fenolik, flavonoid dan tanin yang diperoleh terdapat pada Tabel 1.

Dari Tabel 1 kandungan total fenolik, flavonoid, dan tanin diperoleh ekstrak EA merupakan ekstrak yang paling tinggi kandungan fenoliknya yaitu 325,612 mg/L. Menurut Harborne (1987), senyawa fenolik lebih banyak larut pada ekstrak EA karena sifatnya yang semi polar. Selanjutnya, diikuti dengan ekstrak B yaitu $306,429 \mathrm{mg} / \mathrm{L}$, ekstrak PE yaitu $169,489 \mathrm{mg} / \mathrm{L}$, ekstrak E yaitu 148,469 mg/L, dan ekstrak Aq yaitu $52,551 \mathrm{mg} / \mathrm{L}$. Konsentrasi senyawa fenolik dalam ekstrak ditentukan dengan metode Folin-ciocalteau yang berdasarkan pada kemampuan ekstrak untuk mereduksi reagen folin-ciocalteau (berwarna kuning) yang mengandung asam fosfomolibdat-fosfotungstat yang menghasilkan senyawa kompleks molibdenum tungstant yang berwarna biru, semakin pekat warna yang dihasilkan 
maka kandungan senyawa fenolik dalam ekstrak semakin besar pula (Julkunen-Tiito, 1985).

Total kandungan flavonoid paling tinggi terdapat pada ekstrak EA $53,82 \mathrm{mg} / \mathrm{L}$ diikuti ekstrak PE $36,014 \mathrm{mg} / \mathrm{L}$, ekstrak B 30,942 mg/L, ekstrak E $12,417 \mathrm{mg} / \mathrm{L}$, dan Aq 8,964 mg/L. Total kandungan flavonoid yang tinggi pada ekstrak EA dikarenakan sebagian senyawa flavonoid pada ekstrak EA lebih banyak larut dalam sistem tersebut dibandingkan dengan ekstrak PE, B, E dan Aq. Sedangkan, total kandungan tanin adalah yang paling rendah dari flavonoid dan tanin. Total kandungan tanin yang rendah disebabkan karena senyawa tanin yang terdapat pada ekstrak hanya sedikit yang larut dalam sistem tersebut.

Tabel 1 - Judul Tabel

\begin{tabular}{|c|c|c|c|}
\hline Ekstrak Daun Cengkih & $\begin{array}{c}\text { Kandungan Total Fenolik } \\
(\mathrm{mg} / \mathrm{L})\end{array}$ & $\begin{array}{c}\text { Kandungan Total } \\
\text { Flavonoid }(\mathrm{mg} / \mathrm{L})\end{array}$ & $\begin{array}{c}\text { Kandungan Total Tanin } \\
(\mathrm{mg} / \mathrm{L})\end{array}$ \\
\hline PE & 223,571 & 36,014 & 17,144 \\
\hline EA & 280,918 & 53,82 & 13,256 \\
\hline B & 271,531 & 30,942 & 17,033 \\
\hline E & 148,878 & 12,417 & 12,144 \\
\hline Aq & 111,735 & 8,964 & 12,256 \\
\hline
\end{tabular}

Ket: petroleum eter (PE), etil asetat (EA), $n$-butanol (B), etanol (E) dan akuades (Aq).

\subsection{Kandungan Besi Tereduksi dari Ekstrak Daun Cengkih dengan Cahaya Flouresen}

Gambar 1 menggambarkan bahwa ekstrak EA dengan konsentrasi 1000 ppm memiliki kemampuan yang paling baik dalam memfotoreduksi $\mathrm{Fe}^{3+}$ menjadi $\mathrm{Fe}^{2+}$ pada $0,1,2,3$, dan 5 jam konsentrasi meningkat dari 1,5; 46,917; 84,083; 85,667 dan 87,75 (mg/L). Seiring bertambahnya waktu yang dihasilkan maka konsentrasi semakin tinggi pula hal ini disebabkan karena ekstrak EA yang memiliki senyawa fenolik yang paling tinggi. Menurut Aiken et al. (1985), senyawa fenolik memiliki kemampuan dalam mereduksi beberapa ion logam yang teroksidasi. Hasil ini sejalan dengan hasil kandungan total fenolik yang diperoleh dari ekstrak EA. Ekstrak
PE tidak mampu dalam memfotoreduksi dikarenakan konsentrasi yang diperoleh setiap jamnya tidak menunjukkan meningkatnya konsentrasi, sedangkan untuk ekstrak B pada jam ke-5 konsentrasi yang dihasilkan mengalami penurunan sehingga ekstrak B tidak mampu untuk memfotoreduksi. Dan untuk kedua ekstrak lainnya yaitu E dan Aq tidak mampu dalam memfotoreduksi, hal ini disebabkan karena konsentrasi hanya datar-datar dan tidak menunjukkan pertamabahan yang signifikan, sama halnya dengan ekstrak PE dan B. Dalam hal ini tanpa cahaya dan cahaya merupakan kontrol karena konsentrasi yang diperoleh kecil, hal ini disebabkan tidak terdapat ekstrak melainkan hanya larutan amonium besi sulfat saja.

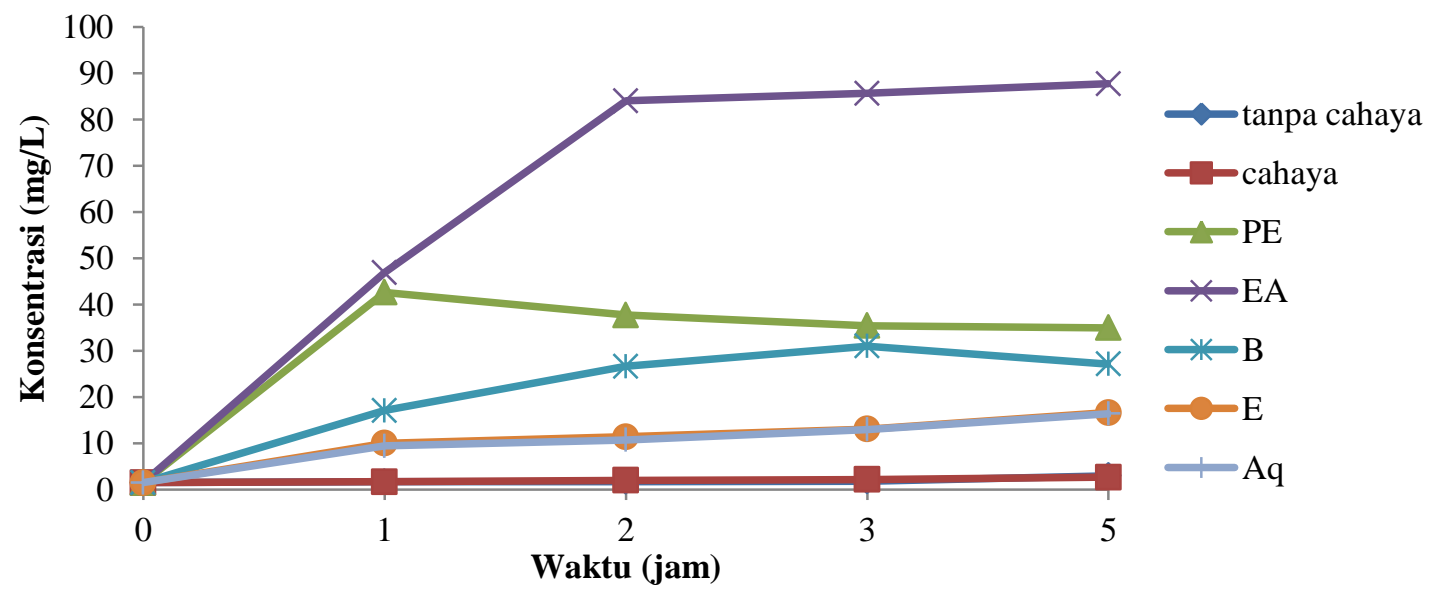

Gambar 1 - Grafik kandungan Fe ${ }^{2+}$ ekstrak daun cengkih 1000 ppm cahaya flourescents (Ket: petroleum eter $(P E)$, etil asetat (EA), $n$-butanol (B), etanol (E) dan akuades (Aq)).

\section{Kesimpulan}

Berdasarkan hasil penelitian dapat ditarik kesimpulan bahwa hasil kandungan fitokimia senyawa fenolik/flavonoid/tanin yang terdapat pada ekstrak daun cengkih memiliki kemampuan dalam efek fotoreduksi, dengan ekstrak etil asetat (EA) yang paling tinggi kandungan senyawa fenolik, flavonoid dan tanin serta memiliki kemampuan yang paling baik 
dalam mereduksi $\mathrm{Fe}^{3+}$ menjadi $\mathrm{Fe}^{2+}$ dibandingkan dengan ekstrak petroleum eter (PE), n-butanol (B), etanol (E), dan akuades (Aq).

\section{Daftar Pustaka}

Aiken, G.R., D.M. Mcknight, R.L. Wershaw, and P. MacCarthy, 1985. Humic Substances in Soil Sediment and Water: Geochemistry, Isolation, and Characterization. John Willey and Sons, New York.

Conde, E.F., M.C. Cadahia, Garcia-Vallejo, B.F.D. Simon, dan J.R.G. Adrados. 1997. Low Molecular Weight Polyphenol in Cork of Quercus Suber. Journal of Agriculture Food Chemistry. 45: 26952700.

Foth, H.D. 1984. Fundamental of Soil Science. Jhon Willey and Sons, New York.

Julkenen-Titto, R. 1985. Phenolic Constituents in the Leaves of Northern Willows: Methods for the
Analysis of Certain Phenolic. Journal of Agriculture Food Chemistry. 33: 213-217.

Meda, A., C.E. Lamien, M. Romito, J. Milliogo, dan O.G. Nacoulina. 2005. Determination of the Total Phenolic, Flavonoid and Proline Content in Burkina Fasan Honey, as well as Their Radical Scavenging Activity. Journal of Food Chemistry. 91: 571-577.

Rorong, J.A., Sudiarso, B. Prasetya, J. Polii-Mandang, E. Suryanto. 2012. Analisis Fitokimia Limbah Pertanian Daun Cengkih (Eugenia aromatica) Sebagai Biosensitizer Untuk Fotoreduksi Besi. Prosiding Seminar Nasional Kimia UNESA; Surabaya, 25 Febuari 2012. Himpunan Kimia Indonesia. Halaman 341-344.

Rorong, J.A., Sudiarso, B. Prasetya, J. Polii-Mandang, E. Suryanto. 2012. Phytochemical Analysis of Water Hyacinth (Eichhornia crassipes) of Agricultural Waste as Biosensitizer for Ferri Photoreduction. Agrivita. 34: 152-160. 